
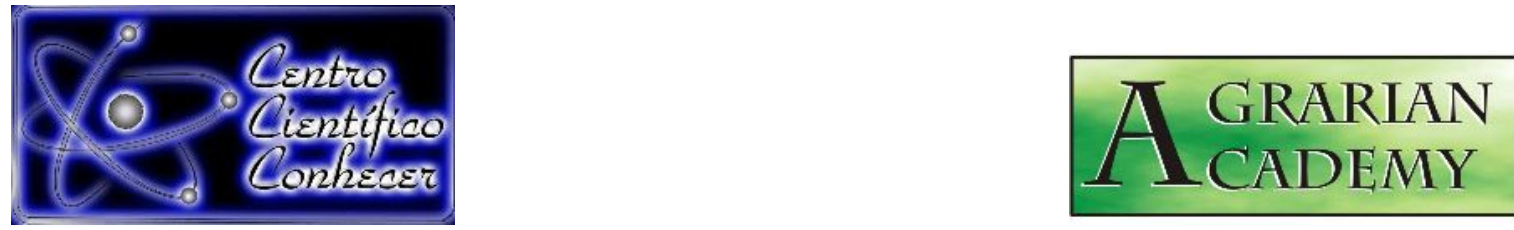

\title{
POVERTY, ENVIRONMENTAL DEGRADATION, AND TAX INCENTIVES IN GOIAS STATE, BRAZIL
}

\author{
Cleyzer Adrian da Cunha ${ }^{1}$; Alcido Elenor Wander ${ }^{2 *}$ \\ ${ }^{1}$ Professor at Federal University of Goiás, Goiânia, GO, Brazil. E-mail: \\ cleyzercunha@gmail.com. \\ ${ }^{2}$ Brazilian Agricultural Research Corporation (Embrapa), Santo Antônio de Goiás, \\ GO, Brazil. *Correspondence author: Embrapa, P.O. Box 179, 75375-000 Santo \\ Antonio de Goias - GO, Brazil. E-mail: alcido.wander@embrapa.br. \\ Recebido em: 02/06/2019 - Aprovado em: 15/06/2019 - Publicado em: 22/07/2019 \\ DOI: 10.18677/Agrarian_Academy_2019a25
}

\begin{abstract}
The aim of this study was to determine whether there is a statistical relationship between land degradation, poverty, and the PRODUZIR program in the municipalities of Goiás state, Brazil. Based on the understanding of this relationship, knowledge of the factors that may cause and feedback into the cycle of poverty can be gained. Thus, interventions can be proposed to minimize the negative impacts on the environment. The estimated results of the logit model show that the municipalities with a high Gini index have on average a higher probability of having incidence of land degradation compared to other municipalities in the state, i.e., in Goiás state, income inequality suggests greater land degradation. However, municipalities in Goiás that use tax incentives through the PRODUZIR program have on average a lower probability of experiencing land degradation compared to other municipalities that do not use this program.
\end{abstract}

KEYWORDS: degradation; logit; tax incentives.

JEL Classification: O1, Q56, Q58

\section{POBREZA, DEGRADAÇÃO AMBIENTAL E PROGRAMA DE INCENTIVOS FISCAIS NO ESTADO DE GOIAS, BRASIL}

\section{RESUMO}

O objetivo do estudo foi verificar se há relação estatística entre a degradação da terra, a pobreza e o Programa PRODUZIR nos municípios goianos. A partir do entendimento dessa relação pode-se ter conhecimento dos fatores que podem causar e retroalimentar o ciclo da pobreza. Desta forma, podem-se propor intervenções que possam contribuir para minimizar os impactos negativos sobre o meio ambiente. Os resultados estimados do modelo Logit mostram que os municípios com alto índice de Gini possuem, em média, uma probabilidade maior de estarem sob a situação de incidência de degradação da terra quando comparado AGRARIAN ACADEMY, Centro Científico Conhecer - Goiânia, v.6, n.11; p. 261 2019 
aos demais municípios do estado. Ou seja, em Goiás, desigualdade de renda sugere maior degradação da terra. Todavia, os municípios goianos que utilizam os incentivos fiscais por meio do Programa PRODUZIR do governo possuem, em média, uma probabilidade menor de apresentarem degradação da terra quando comparados aos demais municípios que não usam o programa.

PALAVRAS -CHAVE: degradação, incentivos fiscais, logit.

\section{INTRODUCTION}

It is known that, in the literature, it is difficult to develop indicators to assess the degree of poverty and to plan effective public policies to reach the poor, because the concept of poverty is broad. In this context, the present study on land degradation and poverty is justified because lack of knowledge of the factors that can cause and feedback into the cycle of poverty in the municipalities in Goiás state, Brazil.

In this manner, interventions can be proposed that can contribute to minimizing the impact of land degradation. In this context, the general objective of the study was to determine whether there is a relationship between land degradation, poverty, and the PRODUZIR [PRODUCING] program ${ }^{1}$ in the municipalities of the state of Goiás. Specifically, we sought to determine which economic factors were decisive in explaining the incidence of land degradation in the 246 municipalities according to the Agricultural Census, the Poverty and Inequality Map of Brazilian Municipalities, the Program PRODUZIR. The data is cross-section and econometric model is logit model.

The contribution of the present study was the inclusion of a proxy variable that sought to capture the effects of the PRODUZIR program tax incentives in Goiás and their consequences for the presence of degraded land. Theoretically, investments in the most dynamic sectors of the economy imply lower pressure on environmental resources, especially in municipalities with low income and a high incidence of poverty.

In addition to this brief introduction, the article is divided into four sections: in section 2, a literature review on the topic is performed; in section 3, the logit econometric model is presented to discuss which socioeconomic variables determine land degradation; in section 4, the results of the estimates of the econometric model are presented and discussed; and finally, in section 5, the conclusions are presented.

\section{LITERATURE REVIEW}

The hypothesis of the vicious cycle of poverty has been explored by various researchers studying problems related to development and underdevelopment. This cycle is presented as a circular and cumulative process that exerts continuous pressure up and down, in a process in which a negative factor is both the cause and effect of other negative factors (Myrdal, 1972). The concept of the vicious cycle involves a circular constellation of forces that tend to act and react independently, which in turn puts a poor country, community, or region in a state of poverty.

According to Nurkse (1952) cited by Myrdal (1972), the cycle translates as follows: "a poor man may not have enough to eat; being underfed, his health may be

\footnotetext{
${ }^{1}$ A tax incentive program of the government of the state of Goiás that encourages the implementation, expansion, or revitalization of industries, encouraging investments, technological innovation, and increased state competitiveness with an emphasis on employment, income generation, and the reduction of social and regional inequalities.
} 
weak; being physically weak, his working capacity is low, which means that he is poor, which in turn means that he will not have enough to eat; and so on".

Rural poverty and its consequences on natural resources and the environment are even more perverse effects. Several studies, such as those by Rodríguez-Meza et al. (2002), Echeverría (1998, 2000), Reardon and Vosti (1995), Waquil and Mattos (2002, 2003), and Finco (2003), have provided evidence of this relationship and pointed to the use of public policies as an alternative for disrupting the circular and cumulative equilibrium.

According to Waquil et al. (2004), the "vicious cycle" of rural poverty and the environment can be viewed as follows: the degradation of natural and environmental resources, in turn, reduces productivity, resulting in the impoverishment of farmers. Therefore, this circle suggests that poverty reduction will necessarily reduce environmental degradation and, similarly, environmental conservation and preservation will necessarily reduce poverty.

Accordingly, the hypothesis that will be tested in this study follows the mainstream view of sustainable development, in which poverty is the leading cause of environmental degradation in small rural communities and in poor regions where, as a trap and a vicious cycle, they must be fought with public policies.

The empirical relationships between municipal indicators of poverty and environmental degradation are in line with the economic literature. Grossman and Krueger $(1991,1995)$ showed that there is a relationship between income and environmental degradation, and the relationship became known as the environmental Kuznets curve (EKC). The EKC concept was based on the study by Kuznets (1955), in which an inverted (U-shaped) relationship between income and economic inequalities was for the first time proposed.

The performance of the study is justified by the understanding that the vicious cycle of poverty and environmental degradation can be supported or refuted in the municipalities of the state of Goiás using a logit econometric model. The variable used in the model was land degradation according to the Agricultural Census of 2006, which is the area of agricultural establishments in which there is degraded land, i.e., land that was eroded, desertified, salinized, etc.

Land degradation leads to low agricultural productivity and therefore low productivity in food production and negative financial and economic performance. Consequently, when considering financial and economic performance as negative in time $t$, the only solution is to use practices that are polluting and aggressive to the local environment in time $t+1$, considering that there are no available resources for appropriate soil management, thus increasing the circular and cumulative process of rural poverty and environmental degradation.

In this context, only investments in more dynamic sectors of the economy, such as industry and trade, can reduce the negative impact on the local environment. This hypothesis was tested using a logit econometric model by inserting a proxy variable that sought to capture the effects of the PRODUZIR program on the incidence of land degradation in the municipalities of Goiás.

\section{ECONOMETRIC MODEL}

In discrete choice models, the coefficients estimated by the logit model do not directly measure the influence of independent variables on the dependent variable. What matters are the marginal effects that should be calculated based on the estimated coefficients. Thus, the marginal effect shows the absolute variation in the dependent variable given by a unitary variation in the independent variable. 
The desired characteristics of the variable receive values equal to $1(y=1)$ and otherwise receive values equal to $0(y=0)$. In this study, the value equal to 1 was used as a dichotomous dependent variable for a municipality's having established degraded land and 0 for a municipality that did not have degraded or desertified land according to the Agricultural Census of 2006.

$\operatorname{Prob}(Y=1 \mid X)=F(X, \beta)$

$\operatorname{Prob}(Y=0 \mid X)=1-F(X, \beta)$

The vector $X$ represents the set of explanatory variables collected by the Brazilian Institute of Geography and Statistics (Instituto Brasileiro de Geografia e Estatística - IBGE) and the Secretariat of Industry and Trade of the State of Goiás, such as the Gini index, poverty incidence rate, GDP per capita, effect of the State Government's PRODUZIR program, and demographic density. These variables were explanatory, i.e., they determine the incidence of land degradation in the municipalities of Goiás in the model.

According to Greene (2008), the set of estimated $\beta$ reflects the positive or negative impact on the change of $x$ over the probability, i.e., only the direction of the impact. However, these estimated coefficients do not represent marginal effects. Considering the linear regression model $F(X, \beta)=X^{\prime} \beta$, the expected value of $E[Y \mid X]=F(X, \beta)$, the regression model can be constructed in matrix form:

$Y=E[Y \mid X]+\left(Y-E[Y \mid X]=X^{\prime} \beta+\varepsilon\right.$

For a given regressor vector, it is expected that:

$\lim _{X^{\prime} \beta \rightarrow+\infty} \operatorname{Prob}(Y=1 \mid X)=1$
$\lim _{X^{\prime} \beta \rightarrow-\infty} \operatorname{Prob}(Y=1 \mid X)=0$

According to Greene (2003), using logistic distribution, the logit model can be constructed as

$\operatorname{Prob}(Y=1 \mid X)=\frac{e^{X^{\prime} \beta}}{1+e^{X^{\prime} \beta}}=\Lambda\left(e^{X^{\prime} \beta}\right)$

where the term $\Lambda($.$) represents the notation for the cumulative logistic distribution$ function. To calculate the marginal effect in general form, discrete choice models require defining probability function. In the general case, the marginal effect is given by

$\frac{\partial E[Y \mid X]}{\partial X}=\left\{\frac{\mathrm{dF}\left(\mathrm{X}^{\prime} \beta\right)}{\mathrm{dF}\left(\mathrm{X}^{\prime} \beta\right)}\right\} \beta=\mathrm{f}\left(\mathrm{X}^{\prime} \beta\right) \beta$

Considering that the function $f($.$) has a logistic distribution, the marginal effects$ of the logit model are

$\frac{\partial E[Y \mid X]}{\partial X}=\Lambda\left(\mathrm{X}^{\prime} \beta\right)\left[1-\Lambda\left(\mathrm{X}^{\prime} \beta\right) \beta\right.$ 
The probability of occurrence is given by $p_{i}=\frac{1}{1+e^{-x_{j} \beta}}$, and the probability of non-occurrence by $1-p_{i}=\frac{e^{-X_{j}}}{1+e^{-X_{j} \beta}}$, still in accordance with the equations of $X_{i}$, the explanatory variables of the logit model; and $\beta$ are coefficients estimated for the explanatory variables.

Thus, the marginal effect of each explanatory variable on the probability is not constant, given that, in most empirical studies, the mean value assumed by each explanatory variable is used by convention. Thus, the marginal effect of the occurrence of the event is given by

$\frac{\partial P\left(Y=1 \mid X_{j}\right)}{\partial X_{J}}=\beta_{j} p_{i}\left(1-p_{\mathrm{i}}\right)=\beta_{\mathrm{j}} \times \frac{1}{1+e^{-X_{j} \beta}} \times \frac{e^{-X_{j} \beta}}{1+e^{-X_{j} \beta}}$

The marginal effect of the continuous variables used in the empirical model may be calculated from the statistically significant estimates. As discussed above, in the analytical method, the coefficients estimated by the logit model do not directly measure the influence of the independent variables on the dependent variable, which means that it is necessary to calculate their marginal effects for this purpose. Thus, the marginal effect shows the absolute variation in the dependent variable given by a unitary variation in the independent variable.

Equation (3) can be rewritten for a multivariate concept, still assuming the logistic distribution function, where:

$Z_{i}=\beta_{1}+\beta_{2} X_{2 i}+\beta_{3} X_{3 i}+\ldots+\beta_{k} X_{k i}$

and the probability of occurrence is given by $P_{i}=\frac{1}{1+e^{-z i}}=\frac{e^{z}}{1+e^{z}}$.

In this equation, $Z_{i}$ varies from $-\infty$ to $+\infty$, and $P_{i}$ varies between 0 and 1 , thus showing the dichotomous character of the model that was observed above. In addition, $P_{i}$ is non-linearly related to $Z_{t}$ (i.e., $\mathrm{X}_{\mathrm{i}}$ ). However, regarding this latter situation, in addition to not being linear in $\mathrm{X}, P_{t}$ is not linear in $\beta$. This situation implies that the ordinary least squares (OLS) method cannot be used to estimate the parameters, although it is possible to linearize the equation.

For this purpose, the odds ratio of a given situation occurring or not will be used; thus, we have:

$L_{i=} \ln \left(\frac{P_{i}}{1-P_{i}}\right)=Z_{i}=\beta_{1}+\beta_{2} X_{2 i}+\beta_{3} X_{3 i}+\ldots+\beta_{k} X_{k i}$

In equation $11, L_{i}$ is the logarithm of the odds ratio, being linear in $X$, as in the parameters. Gujarati (2011) notes some features of the logit model:

1) When $P$ goes from 0 to 1 (when $Z$ varies from $-\infty$ to $+\infty$ ), logit $L$ goes from $-\infty$ to $+\infty$. However, when probabilities remain between 0 and 1 , logits are not restricted.

2) Although $L$ is linear in $X$, the probabilities themselves are not.

3) As many regressors may be added to this model as allowed by the theory.

4) If $L$ is positive, the implication is that, when the value(s) of the regressor(s) increase(s), the odds of the regressand being equal to 1 also increase. If $L$ is 
negative, the opposite occurs, i.e., the odds of the regressor being equal to 1 decrease as the value of $X$ increases.

5) The interpretation of the model based on equation (10) is $\beta_{2}$, the slope, measures the variation in $L$ for a unit variation in $X$. The intercept $\beta_{1}$ is equal to the value of the logarithm of the odds in favor of a situation, when $X$ is equal to 0 and may not have any physical meaning.

6) The logit model assumes that the logarithm of the odds ratio is linearly related to $\mathrm{X}_{\mathrm{i}}$.

In this context, the OLS estimation using the following equation (11) is not feasible. However, the estimation may be performed using the maximum likelihood $(\mathrm{ML})$ method to estimate the parameters with the aid of software. In the present study, the R software was used.

The marginal effects (ME) of the significant variables can be calculated in the midpoint of the data for each estimated coefficient:

$\mathrm{ME}=\frac{\mathrm{e}^{\mathrm{x}^{\prime} \beta}}{1+\mathrm{e}^{\mathrm{x}^{\prime} \beta}}\left\langle 1-\frac{\mathrm{e}^{\mathrm{x}^{\prime} \beta}}{1+\mathrm{e}^{\mathrm{x}^{\prime} \beta}}\right\rangle \beta$

According to Gujarati (2011), some general observations about the logit model can be made:

1) The maximum likelihood method, in general, is a method of large samples and will have the estimated asymptotic standard errors.

2) Z statistics (normal) will be used to evaluate the statistical significance of a coefficient.

3) The conventional measure of goodness of fit, $R^{2}$, is not significant in binary regressand models. In this case, the pseudo $R^{2}$ or McFadden $R$-squared is used.

Finally, in the study's aim was to analyze the sensitivity of the estimated value logit model for the probability of the impact of tax incentives on land degradation. In the paper we used bootstrapping simulation for the marginal effect of the tax incentives parameter. Bootstrapping is a type of resampling where large numbers of smaller samples of the same size are repeatedly drawn, with replacement by an original sample. Therefore, the simulation generates a sample of random numbers for the marginal effect.

\section{DATA SOURCE}

Data were collected according to their availability to the 246 municipalities in Goiás. Regarding the tabulation of the cross-sectional data, some criteria were used, namely: a) some municipalities were excluded from analysis due to the lack of relevant information, including Campo Limpo de Goiás, Gameleira de Goiás, Lagoa Santa and Ipiranga de Goiás; b) because the dependent variable $Y$ used in the logit model is dichotomous, a value equal to 1 was assumed for municipalities with degraded land and 0 for municipalities with no degraded or desertified land according to the Agricultural Census of 2006. Thus, the cities with degradation of land assumed of 10 otherwise. c) the variables that explain the presence of degradation were $\mathrm{X} 1=$ the Gini index, ranging from 0 to 1 , where the closer to 1 the index is, the more unequal the municipality. The Gini index measures the extent to which the distribution of income among households within an economy deviates from a perfectly equal distribution. Thus, a Gini index of 0 represents perfect equality, while 
an index of 1 implies perfect inequality. The Index were collected at the IBGE through the Poverty and Inequality Map, Brazilian Municipalities, 2003. The variable GDP and demographic density were collected at the IBGE through the Cidades @ to 2010 year. Finally, incidence of poverty in the population were collected the Poverty and Inequality Map. Therefore, X2 = the logarithm of GDP per capita in R $\$$ of 2010; X3 = the incidence of poverty in the population; and $X 4=$ whether there is a specific law that encourages the use of the PRODUZIR program. The variable is dummy to the PRODUZIR program.

Therefore, with respect to the variable $\mathrm{X} 4$, if the municipality had a specific municipal tax incentive law, it received a value equal to 1 , otherwise equal to 0 . The information was collected from the Secretariat of Industry and Trade of the State of Goiás. The variable is a dummy that was constructed by the authors in the research. The Cities that have the PRODUZIR program received 1 and 0 otherwise. This variable sought to capture the effects of tax incentives on the occurrence of environmental degradation, where a negative marginal effect is expected, indicating that the municipalities that legally encourage the PRODUZIR program tend to reduce the incidence of environmental degradation. In this context, the effect would be residual, given that new investments in other dynamic sectors in the municipalities would reduce the pressure on agricultural land to generate wealth. X5 = demographic density (inhabitants $/ \mathrm{km}^{2}$ ), which provides evidence for the availability of land for exploitation, indicating that regions with higher coefficients would tend to put pressure on the land until its exhaustion.

\section{RESULTS AND DISCUSSION}

To test whether there is statistical relationship between desertification and the other explanatory variables, such as per capita income, the Gini index, the poverty index, demographic density, and the proxy for tax incentives, the logit model was estimated. The model results are presented in Table 1 shows that the tax incentives had a negative sign and statistical significance, supporting the hypothesis that, in municipalities with specific tax incentives laws, the pressure on the desertification area of Goiás is reduced.

TABLE 1. Estimated results of the logit model.

\begin{tabular}{lllll}
\hline Variable & Coefficient & Standard deviation & Z statistic & P-value \\
\hline C & -3.865451 & 3.059343 & -1.26349 & $0.2064^{\text {ns }}$ \\
X1 & 16.45779 & 7.649504 & 2.151484 & $0.0314^{*}$ \\
X2 & -0.586295 & 0.64702 & -0.90615 & $0.3649^{\text {ns }}$ \\
X3 & -0.033854 & 0.014846 & -2.28041 & $0.0226^{*}$ \\
X4 & -0.568764 & 0.333372 & -1.70609 & $0.088^{\star *}$ \\
X5 & 0.00324 & 0.003035 & 1.067623 & $0.2857^{\text {ns }}$ \\
\hline
\end{tabular}

Source: study data. Note: Study results: * significant at $5 \%,{ }^{* *}$ significant at $10 \%$, and ns is statistically non-significant. McFadden $R$-squared $=0.036076$. The variable $\mathrm{C}$ is a constant of model.

The variables in Table 1 are coded as follows:

a) $\mathrm{Y}=$ a dichotomous variable that provides evidence for the presence of degraded lands (eroded, desertified, salinized, etc.), where $Y=1$ if there is an area with degradation and $\mathrm{Y}=0$ otherwise;

AGRARIAN ACADEMY, Centro Científico Conhecer - Goiânia, v.6, n.11; p. 267 
b) $\mathrm{X} 1=$ the Gini Index;

c) $\mathrm{X} 2=$ the logarithm of the GDP per capita in $\mathrm{R} \$$ at 2010 prices;

d) $\mathrm{X} 3=$ the poverty incidence index;

e) X4 = a proxy for tax incentives (specific law for the PRODUZIR program); and

f) $\mathrm{X} 5=$ population density (inhabitants $/ \mathrm{km}^{2}$ ).

Furthermore, according to Table 1, the estimated parameter for the Gini coefficient was high and positive, in addition to being statistically significant. This result reinforces the positive relationship between the two variables, i.e., an increase in inequality increases the incidence of arable land degradation. Thus, the result confirms the proposed EKC curve, where the negative effects on the environment are greater in poor regions. That is, in Goiás, the municipalities with the highest Gini indexes were those that had the highest incidences of land degradation.

The income variable had a sign consistent with the theory, given that municipalities with higher income values had a lower incidence of degradation. However, this result cannot be interpreted because the estimated parameter is not statistically significant. Thus, it was not confirmed that income is a determinant factor in reducing the incidence of degradation. This result was due to the heterogeneity of the sample composed of the municipalities of the state of Goiás.

The estimated coefficient for tax incentives was statistically significant and had a sign consistent with the hypothesis that investments in more dynamic sectors such as industry and services tend to reduce pressure on the environment. Therefore, municipalities that have specific legislation in line with the PRODUZIR program tend to reduce pressure on the incidence of land degradation. This result indicates that public policies can be used to boost the economy, which mainly leads to lower pressure on the environment. Finally, the demographic density variable was statistically non-significant; thus, inferences cannot be made on the model.

Finally, regarding the magnitude of the coefficients, as shown in the methods, because the regression is non-linear, the coefficients shown in Table 1 do not represent marginal effects. The marginal effect of each independent variable for the logistic distribution may be obtained using equations (12) (given the estimated results, the marginal effect was calculated only for variable X1) (Equation 12).

From equations (12), in the midpoint of the variable $\mathrm{X} 1$, the marginal effect found was +16.2 , indicating that municipalities with a higher Gini index have, on average, a $16.2 \%$ higher probability of having incidence of land degradation compared to other state municipalities. Therefore, inequality and poverty increase the impact on the environment, according to the indications of the EKC curve.

For the variable measuring tax incentives (X4), based on equation (12) in the midpoint of the variable, the marginal effect was found to be -0.07 , indicating that municipalities that use the PRODUZIR program tax incentives have, on average, a $7 \%$ lower probability of having incidence of land degradation compared to other municipalities that do not use the program.

Nevertheless, the next step in the study was to analyze the sensitivity of the estimated value for the probability of the impact of tax incentives on land degradation. Doing so was accomplished by bootstrapping simulation in $\mathrm{R}$ software. This analysis shows the exact value of the probability of the occurrence of the parameter estimated in the logit model for the simulated random sample of 1,000 random numbers with a variation of $30 \%$. The results are shown in Figure 1. 


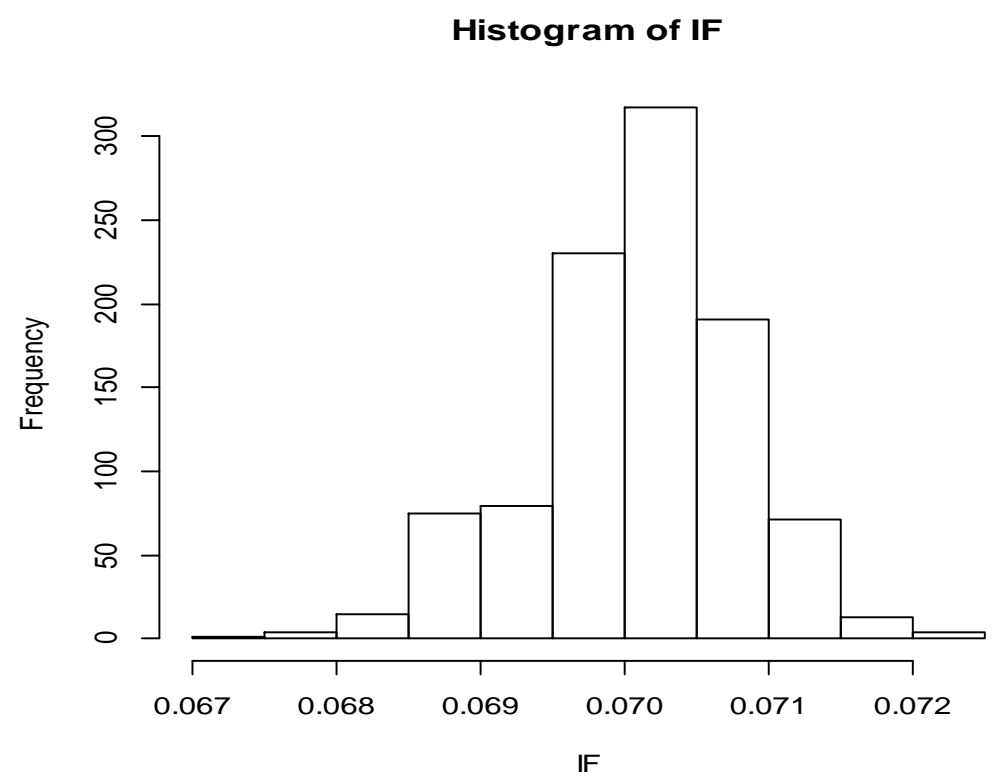

FIGURE 1. Bootstrapping simulation for the marginal effect of the tax incentives (IF) parameter.

Source: Research results.

According to Figure 1,95\% of the results are around the value of $7 \%$ for the marginal effect, which shows that the effects of the random sample tend to approach the value estimated in the logit model. Therefore, the value of the marginal effect of $7 \%$ is consistent with the simulation and can be used for decision making in shaping public policies on tax incentives.

\section{CONCLUSION}

Given the estimated model, it is concluded that municipalities with a higher Gini index have, on average, a higher probability of experiencing incidence of land degradation compared to other municipalities in the state.

In addition, the municipalities of Goiás that use tax incentives through the PRODUZIR government program have, on average, a lower probability of having land degradation compared to other municipalities that do not use the PRODUZIR program.

Finally, these results show that the poorest municipalities in the state are under a strong situation of incidence of land degradation and that the tax incentives law tends to reduce the probability of this situation compared to municipalities that do not have a specific municipal law regulating the PRODUZIR program.

\section{COMPLIANCE WITH ETHICAL STANDARDS}

Conflict of interest: The authors declare that they have no conflict of interest.

Funding: This study was funded by Fundação de Amparo à Pesquisa do Estado de Goiás (FAPEG).

Open Access: This article is distributed under the terms of the Creative Commons Attribution 4.0 International License (http://creativecommons.org/licenses/by/4.0/), which permits unrestricted use, distribution, and reproduction in any medium, 
provided you give appropriate credit to the original author(s) and the source, provide a link to the Creative Commons license, and indicate if changes were made.

\section{REFERENCES}

BARBIER, E. The economic linkages between rural poverty and land degradation: some evidence from Africa. Agriculture, Ecosystems and Environment, v.82, n.1, p.355-370, 2000. DOI: https://doi.org/10.1016/S0167-8809(00)00237-1.

BROAD, R. The poor and the environment: friends or foes? World Development, v.22, n.6, p.811-822, 1994. DOl: https://doi.org/10.1016/0305-750X(94)90055-8.

CAVENDISH, W. Empirical regularities in the poverty-environment relationship of African rural households. Centre for the Study of African Economies, Institute of Economics and Statistics, University of Oxford. 1999. Available at: https://core.ac.uk/download/pdf/6232386.pdf.

ECHEVERRÍA, R.G. Elementos estratégicos para la reducción de la pobreza rural en América Latina y el Caribe. Washington: IDB, 1998.

ECHEVERRÍA, R.G. Opciones para reducir la pobreza rural en América Latina y el Caribe. Revista de la CEPAL, v.70, p.147-160, 2000. Available at: https://repositorio.cepal.org/bitstream/handle/11362/12205/070147160_es.pdf?seque nce $=1$ \&isAllowed $=\mathrm{y}$.

FINCO, M.V.A. Pobreza rural e degradação ambiental: uma refutação da hipótese do ciclo vicioso no Rio Grande do Sul. Master Thesis in Rural Development, Federal University of Rio Grande do Sul (UFRGS), Porto Alegre, RS, Brazil. 2003. Available at: http://hdl.handle.net/10183/4013.

GREENE, W.H. Econometric Analysis. $6^{\text {th }}$ ed. New Jersey: Prentice Hall, 2008.

GROSSMAN, G.M.; KRUEGER, A.B. Environmental Impacts of a North American Free Trade Agreement. In: GARBER, P. (ed.). The Mexico - U.S. Free Trade Agreement. Cambridge, MA: MIT Press, 1993.

GROSSMAN, G.M.; KRUEGER, A.B. Economic Growth and The Environment. Quarterly Journal of Economics, v.110, n.2, p.353-377, 1995. DOI: https://doi.org/10.2307/2118443.

GUJARATI, D.N. Econometria básica. $3^{\text {rd }}$ ed. São Paulo: Makron Books, 2011.

KUZNETS, S. Economic Growth and Income Equality. American Economic Review, v.45, n.1, p.1-28, 1955. Available at: https://www.jstor.org/stable/1811581.

MYRDAL, G. Teoria econômica e regiões subdesenvolvidas. $3^{\text {rd }}$ ed. Rio de Janeiro: Editora Saga, 1972.

NURKSE, R. Some aspects of accumulation in under-developed countries. Cairo: National Bank of Egypt, 1952. 
REARDON, T.; VOSTI, S. Links between rural poverty and the environment in developing countries: asset categories and investment poverty. World Development, v.23, n.9, p.1495-1506, 1995. DOI: https://doi.org/10.1016/0305750X(95)00061-G.

RODRÍGUEZ-MEZA， J.; SOUTHGATE, D.; GONZÁlEZ-VEGA， C. Rural development, poverty and agricultural land use in EI Salvador. 2002. Available at: http://www.agecon.ag.ohiostate/programs.

SOUTHGATE, D.; HOPKINS, J.; GONZÁLEZ-VEGA, C.; RODRÍGUEZ-MEZA, J. Rural Poverty, Income Shocks, and Land Management: An Analysis of the Linkages in El Salvador. AAEA Annual Meeting, Chicago, 2001. Available at: https://ageconsearch.umn.edu/record/20646/files/sp01so04.pdf.

WAQUIL, P.D.; MATTOS, E.J. Distribuição de renda no Rio Grande do Sul: um comparativo entre o rural e o urbano. Revista Ensaios FEE, v.23, n.Edição Especial, p.621-644, $2002 . \quad$ Available at: https://revistas.fee.tche.br/index.php/ensaios/article/viewFile/2023/2404.

WAQUIL, P.D.; MATTOS, E.J. Pobreza rural e urbana no Rio Grande do Sul: uma análise além da renda. Porto Alegre: PGDR/UFRGS, 2003.

WAQUIL, P.D.; FINCO, M.V.A.; MATTOS, E.J. Pobreza Rural e Degradação Ambiental: uma Refutação da Hipótese do Círculo Vicioso. Revista de Economia e Sociologia Rural, v.42, n.2, p.317-340, 2004. DOI: http://dx.doi.org/10.1590/S010320032004000200007. 